\title{
DESIGN OF SVRAČKOVO DAM CONCRETE STRUCTURES
}

\author{
Vicko Letica ${ }^{1}$ \\ Vladislav Skoko ${ }^{2}$
}

UDK: 624.012.45:627.8

DOI: $10.14415 /$ konferencijaGFS2021.24

Summary: The Arilje reservoir is multi-purpose and is primarily used for water supply. The Svračkovo dam, is $68.00 \mathrm{~m}$ high. The dam has been designed as a rockfill dam type. The morning glory structure, $56.00 \mathrm{~m}$ high, with conveying tunnel and stilling basin has been designed. For the purpose of water supply and guaranteed minimum discharge, the water intake tower, with height of $60.50 \mathrm{~m}$, has been designed. In addition to the hydrostatic load, the structural analysis has been carried out for the seismic load as dominant.

Keywords: morning glory, water intake, concrete, earthquake

\section{DESCRIPTION}

Svračkovo project site of dam Arilje is located on the Veliki Rzav River, near village Svračkovo, $8.5 \mathrm{~km}$ upstream from town Arilje. The main purpose of reservoir Arilje is water supply and an electricity production in HPP, close downstream to dam. The fill dam type with inclinated central clay core and upstream and downstream supporting filter shells has been designed. The structural height of dam is $68.00 \mathrm{~m}$.

The morning glory structure with conveying tunnel and stilling basin is envisaged for the purpose of maximum designed floods evacuation. The opening diameter of the morning glory overflow edge is $26.60 \mathrm{~m}$, while the inner diameter at bottom part amounts $8.50 \mathrm{~m}$. The inner diameter of the conveying tunnel is $8.50 \mathrm{~m}$, too. The air supply for aeration is provided by the vent pipe with diameter of $1.40 \mathrm{~m}$. At the downstream end of conveying tunnel, the transition section of spillway is situated, which guides water into the spillway stilling basin.

The morning glory comprises vertical monolithic, conditionally axisymmetric reinforced concrete structure. The total height, up to the foundation level, amounts about $56.00 \mathrm{~m}$. The morning glory consists of the free standing above-ground part with bellmouth shape and the underground part formed of the pipe elbow structure. The height of above-ground part is around $20.00 \mathrm{~m}$, while the depth of underground part amounts is around $13.00 \mathrm{~m}$. The thickness of cylinder wall at above-ground part of morning glory is variable, from 1.70 to $2.00 \mathrm{~m}$. The thickness of cylinder wall at underground part is $2.00 \mathrm{~m}$ thick, while

\footnotetext{
${ }^{1}$ Mr.dipl.gradj.inž., Beograd BRANE-HPP-WTP. d.o.o office@brane-hpp-wtp.com

${ }^{2}$ Dipl.gradj.inž., Beograd Energoprojekt-Hidroinzinjering d.o.o.
} 
Савремена достигнућа у грађевинарству 22-23. април 2021. Суботица, СРБИЈА

the thickness of the foundation slab is variable, from 2.00 to $2.30 \mathrm{~m}$. In the phase of river diversion, the tunnel is intended to serve as a bypass tunnel, which later it will be closed upstream from the vertical curve with a concrete plug.

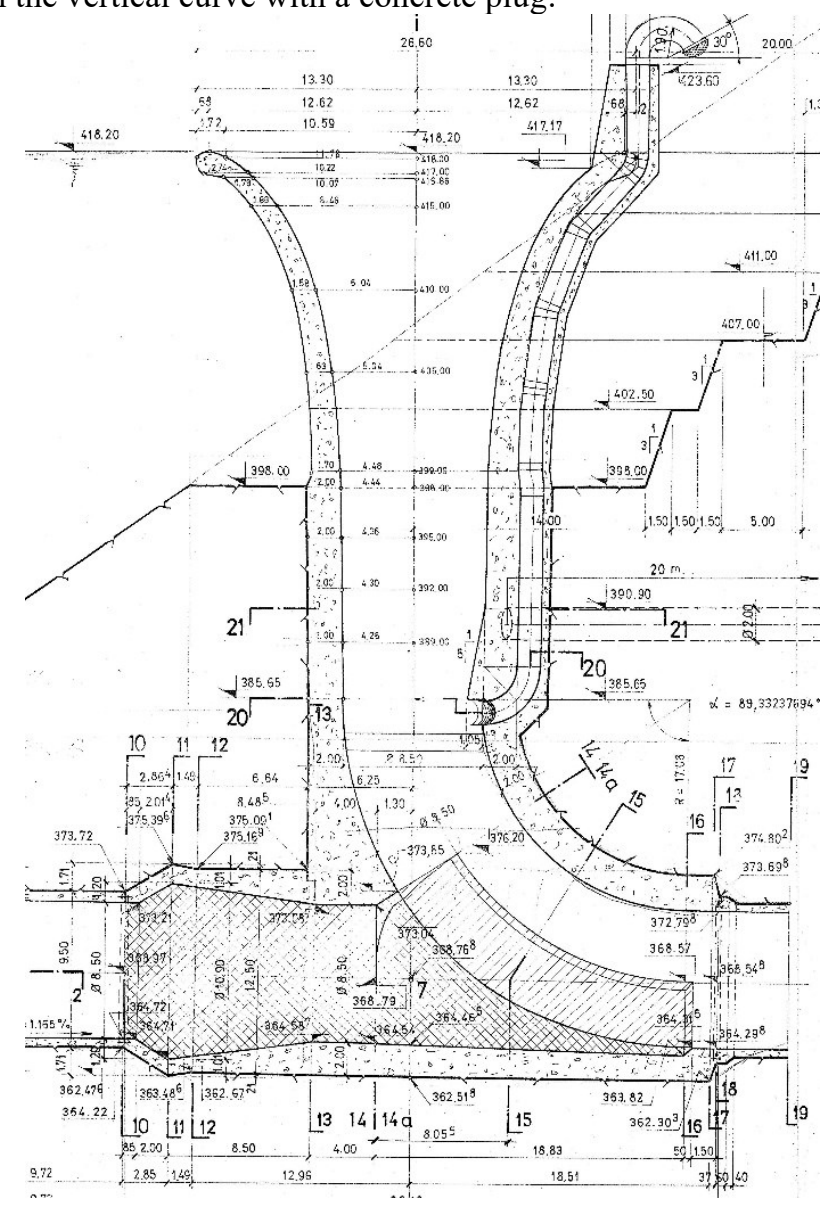

Figure 1. Morning glory

At the location of the morning glory, highly altered Porphyrites are present on the surface. In the deeper zones, compact, unaltered, solid Porphyrites, have been investigated. In order to achieve an intimate connection at the underground part of the morning glory, between the concrete wall and the surrounding rocks, a connecting injection is planned. Due to the geological conditions at the location of the morning glory, in order to achieve restraint of structure, an additional connection of the structure with the rock was designed. The restraint has been provided by a system of horizontal piles with a diameter of $2.00 \mathrm{~m}$ and a length of $20.00 \mathrm{~m}$.

Stability of the morning glory structure has been checked for the stability against uplift for different water levels during operation stage. One of the criteria for determining the wall thickness at the aboveground part of structure has been to provide safety against uplift and to bring the tension stress in the concrete to minimum values. Stability analysis of the 
Contemporary achievements in civil engineering 22-23. April 2021. Subotica, SERBIA

morning glory structure has showed that the tension stresses, with low values, appeared, at the curved part of the wall. However, it has also been shown that these tension stresses in concrete are small, so the minimal reinforcement is sufficient for the stability of the uplift.

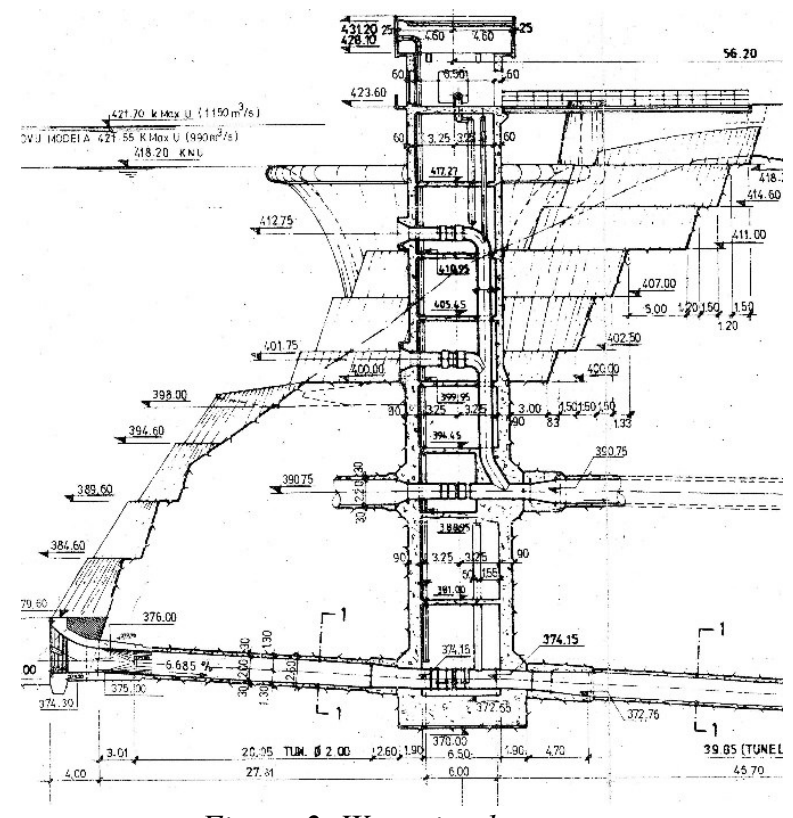

Figure 2. Water intake tower

The water intake tower combines water intake for the water supply and the guaranteed water minimum. The bottom outlet valves are applied at the water intake tower, so the tower is dry inside. The water intake tower is located at the left river bank and connected with coast by the access bridge. The three intake openings are envisaged at the different water level. Along the height of tower, at the intake positions and between them, on distances of 5.10 or $7.55 \mathrm{~m}$, the reinforced concrete slabs, with the thickness of $0.40 \mathrm{~m}$, are situated. The capacities of water intakes and bottom outlet tunnel provide simultaneous intake of maximum utilities for water supply of $2500 \mathrm{l} / \mathrm{sec}$. The power unit with crane for equipment erection is located on the top of water intake tower.

As the morning glory, the water intake tower is cylindrical reinforced concrete structure, with the inner diameter of $6.50 \mathrm{~m}$. The total height is around $20.00 \mathrm{~m}$, The thickness of cylinder wall at above-ground part of the tower is $0.60 \mathrm{~m}$. The cylinder wall at underground part is $0.90 \mathrm{~m}$ thick. The thickness of foundation slab is $2.50 \mathrm{~m}$.

\section{DYNAMIC ANALYSIS}

Dynamic analysis has been carried out at two stages. At the first stage, the modal superposition procedure has been obtained, applying the approximate pseudo structural method of calculation. For modal superposition method of calculation, the structure has 
Савремена достигнућа у грађевинарству 22-23. април 2021. Суботица, СРБИЈА

been approximated with the frame member, restrained in the rock. The frame member has been discretised by the system of nodes with concentrated masses, as well as masses of the surrounded water. 14 concentrated masses have been adopted along the height of structure. At the underground part of structure, the interaction with surrounded rock has been simulated by the system of horizontal springs, considering linear variation of the deformation moduls along the height.

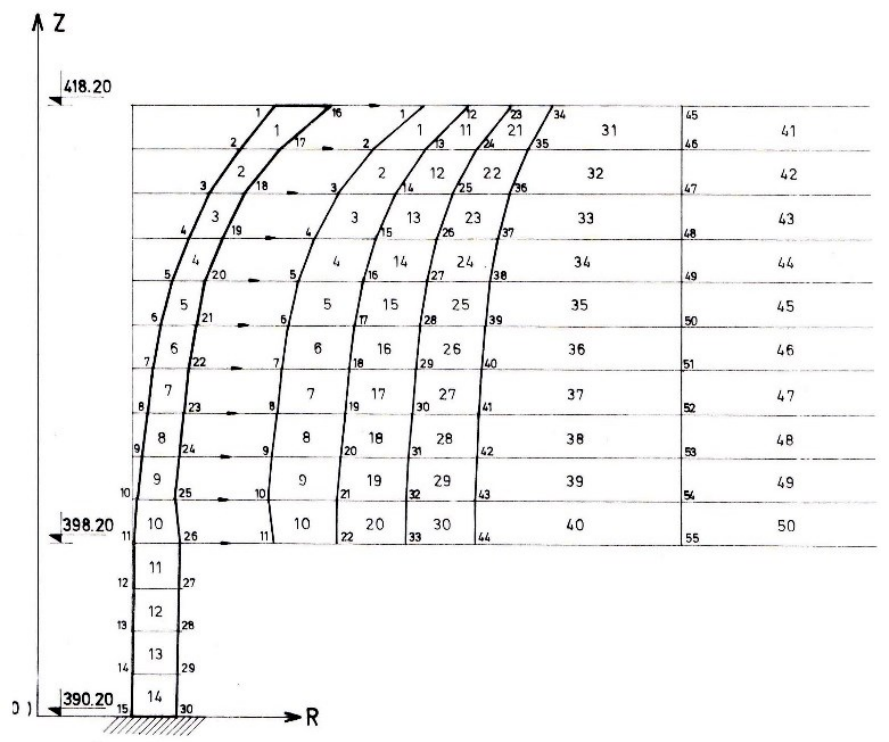

Figure 3. Mesh for FE and BE

Based on the certain strong motion record at the foundation, more precise dynamic analysis, has been performed. Time history earthquake response analysis, using the „step by step" method, is based on linear-elastic analysis has been used for the calculation.

With the support of computer program EASTW, which has been modified and upgraded, the precise analysis of response for the axisymmetric structure submerged in water under to earthquake ground motion impact has been carried out. It has to be noticed that this program has been calculating seismic response, considering the interaction between structure and surrounded water. The axisymmetrical structure has been approximated with the sub-parametrical FE. The surrounded water has been approximated with „boundary elements", as well. The essential point of this program has been an extension of the basic dynamic equations for the structure with the hydrodynamic forces of surrounded water. The hydrodynamical interaction, based on the Laplace equation in cylindrical coordinates has been used for the calculation. The following assumptions established: compressibility and viscosity of water and appearance of waves on the free surface have been neglected. Also, small deformations have been assumed. The boundary conditions for water structure have been, as follows: the movement change along the contact between structure and water has been equal to the impact force of water, while the pressure on free surface and the pressure change along the rest of contours have been equal zero. The result of the dynamic response of the structure was deformation and stress values. 
Contemporary achievements in civil engineering 22-23. April 2021. Subotica, SERBIA

The shape of structure and the scope of foundation, it has been assumed that the height of structure above the relative restraint position has been $28.0 \mathrm{~m}$. As the height of water of $20.0 \mathrm{~m}$, so the depth of relative restraint position has been $8.0 \mathrm{~m}$. For calculation the influences of the strong motion record Petrovac, the duration from 0.00 to $16.30 \mathrm{sec}$ has been chosen. According to the energy flux diagram, after $16.00 \mathrm{sec}$ there is no significant increase in energy.

The record given in $0.02 \mathrm{sec}$ steps, has been interpolated to a step of $0.005 \mathrm{sec}$. The calculation has been performed for three mode shapes of oscillation, with assumed damping for all three mode shapes of $5 \%$. The values of acceleration have been modified on max $\mathrm{Ag}=0.187 \mathrm{~g}$. The check of the influences for San Fernando earthquake record, with the duration of $13.44 \mathrm{sec}$ has been carried out, as well.

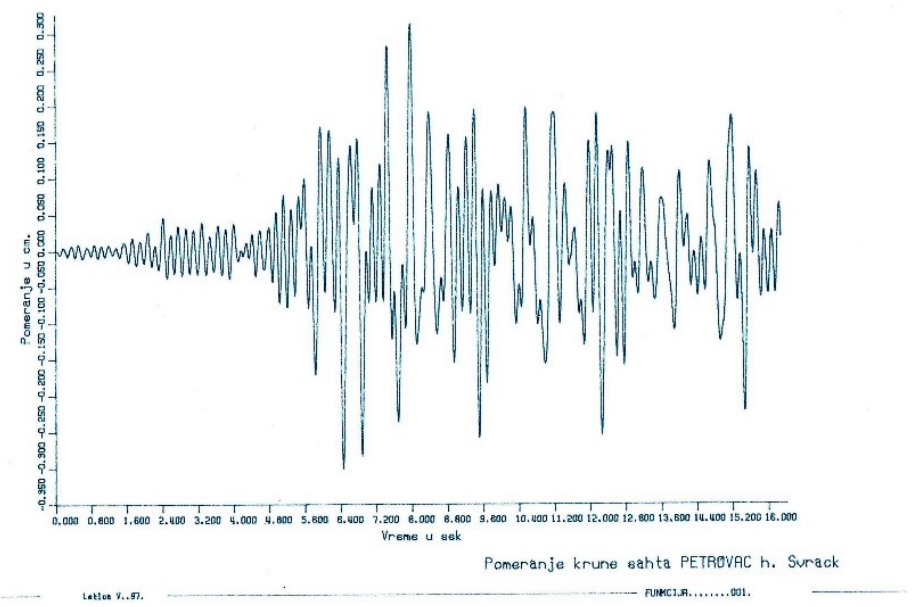

Figure 4. Earthquake response

On the basis of dynamic analysis, the oscillation period eigenvalue of $6.56 \mathrm{~Hz}$ has been obtained. The calculation results have revealed that San Fernando earthquake record has been relevant for proportioning. The maximum values have appeared at the moment $\mathrm{t}=8.57 \mathrm{sec}$, exactly when maximum acceleration has occurred. The maximum tension stress of 2.02 MPa, the maximum compression stress of 3.24 MPa and the maximum shear stress of $0.74 \mathrm{MPa}$ have been obtained for the earthquake load case. The analysis of calculated stress stages has led to the following conclusions: for determination of circular reinforcement, the self weight load without influence of surrounded water has been relevant, while for definition of the vertical reinforcement amount, the earthquake load with influence of surrounded water has been prevailing. The crack width calculation has been carried out in accordance with SNIP standards.

Based on dynamic analysis of the water intake tower, it may be noticed that the oscillation period eigenvalues have been within the limits from 2.50 to $3.70 \mathrm{~Hz}$, while for the system, it have had values between 2.30 and $3.50 \mathrm{~Hz}$.

The reinforced hydrotechnical concrete class MB 30 for all structural elements is envisaged. The concrete is constructed with the admixtures against water permeability V8 and frost resistance M 100. At the inner face of morning glory structure, where the bearing 
8.

МЕЂУНАРОДНА КОНФЕРЕНЦИЛА

Савремена достигнућа у грађевинарству 22-23. април 2021. Суботица, СРБИЈА

reinforcement has a larger clear cover, the construction reinforcement is placed. The reinforcement grade B500B is applied.

As the construction stage of this structures is, currently, in a progress, a few representative photos of the site are presented in the addition.

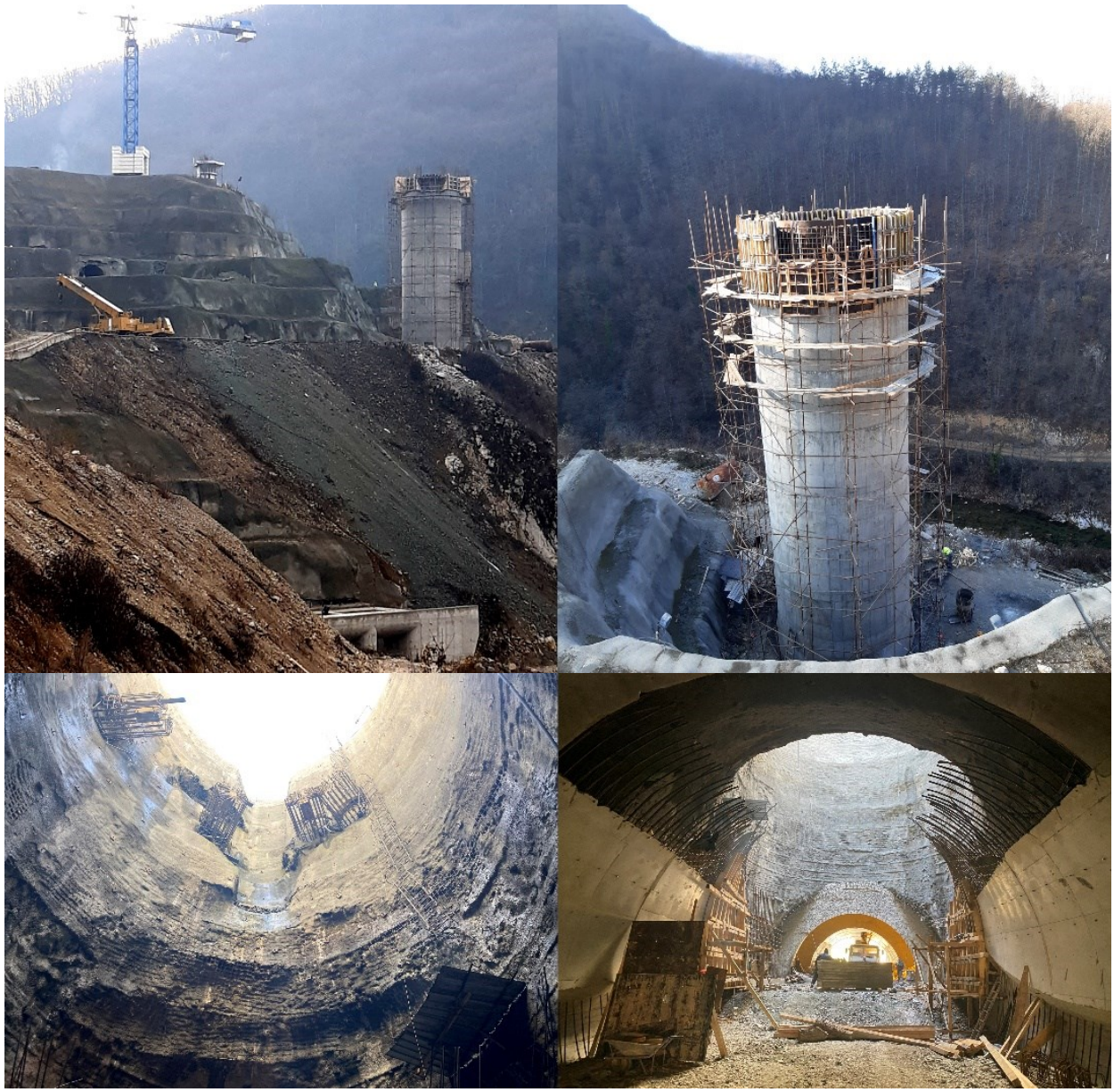

Figure 5. Morning glory-site

\section{REFERENCES}

[1] Energoprojekt-Hidroinženjering: Glavni projekat -Brana i akumulacija Arilje na profilu Svračkovo -1999. godina 